\title{
STUDI EKSPLORATIF TENTANG FAKTOR-FAKTOR PENYEBAB KETERLAMBATAN BICARA ANAK USIA PRA SEKOLAH
}

\section{AN EXPLORATIVE STUDY ON THE FACTORS OF SPEECH DELAY IN PRE SCHOOL AGE CHILDREN}

\author{
Bella Amanda Maharani \& Zainal Abidin \\ Universitas Padjadjaran \\ corresponding email: bella11005@mail.unpad.ac.id
}

\begin{abstract}
Speech or language delay is one of the complaints experienced by children. Research is needed to find out more about the factors of the causes of speech delays experienced by preschoolers. The purpose of this study was to explore the factors that cause speech delays in preschool children in Bandung Regency using an exploratory qualitative method. Data was collected by conducting interviews and observations to three subjects who are mothers of children who experience speech delays. The results of the factors causing speech delay in preschool age children consist of environmental factor and genetic factor. Parents are expected to prevent and deal with the problem of speech delays in children from an early age.
\end{abstract}

Keywords: causative factors, language development, preschool children, speech delay

\begin{abstract}
ABSTRAK
Keterlambatan bicara atau bahasa menjadi salah satu permasalahan yang dialami oleh anak. Dibutuhkan penelitian untuk mengetahui lebih lanjut mengenai faktor-faktor penyebab keterlambatan bicara yang dialami oleh anak usia prasekolah. Tujuan dari penelitian ini adalah mengeksplorasi faktor-faktor penyebab keterlambatan bicara pada anak usia prasekolah di Kabupaten Bandung dengan menggunakan metode kualitatif exploratory. Pengumpulan data dilakukan dengan wawancara dan observasi kepada tiga subjek yang merupakan ibu dari anak yang mengalami keterlambatan bicara, analisis tematik terhadap data menunjukkan hasil bahwa faktor penyebab keterlambatan bicara pada anak usia prasekolah dapat diklasifikasikan ke dalam dua faktor, yakni faktor lingkungan dan faktor keturunan. Orang tua diharapkan dapat mencegah dan menangani permasalahan keterlambatan bicara pada anak sejak dini.
\end{abstract}

Kata Kunci: anak usia pra sekolah, faktor penyebab, keterlambatan bicara, perkembangan bahasa

\section{PENDAHULUAN}

Bahasa adalah kode sosial atau sistem konvensional untuk mewakili konsep melalui penggunaan simbol atau aturan yang telah ditetapkan (Owens, 2012). Bentuk bahasa yang digunakan oleh manusia dibagi menjadi dua, yaitu bahasa ekspresif dan reseptif. Bahasa ekspresif adalah bahasa yang diproduksi dengan ucapan atau tulisan, 
sedangkan bahasa reseptif adalah bahasa yang diterima serta diproses oleh seseorang (Owens, 2012). Anak akan mulai mengenal bahasa melalui bahasa ekspresif yaitu menangis. Baru setelahnya sesuai dengan perkembangan, anak mulai mempelajari bahasa reseptif. Perkembangan bahasa anak normal melalui tahapan menangis, cooing, babbling, kata, dan kombinasi kata-kata. Perkembangan bahasa anak ini akan terus dialami oleh anak sampai memasuki usia sekolah (Berk, 2013).

Tahapan dalam perkembangan bahasa ada kalanya mengalami keterlambatan dan dapat menjadi sebuah gangguan. Gangguan bahasa yang paling umum dan mudah dikenali adalah keterlambatan bicara. Istilah keterlambatan berarti bahwa perkembangan bahasa atau keterampilan berbicara lebih lambat dari yang diharapkan untuk usia dan mengikuti pola perkembangan yang biasanya (Feldman, 2005). Keterlambatan bicara anak diasosiasikan dengan hambatan dalam membaca, menulis, perhatian, dan sosialiasi. Pada umumnya, mereka mempunyai perkembangan intelegensi dan sosial-emosional yang normal (Suparmiati, Ismail, \& Sitaresmi, 2013). Terdapat beberapa ciri-ciri pada perkembangan bahasa reseptif dan ekspresif anak yang menunjukkan keterlambatan dan membutuhkan evaluasi lebih lanjut (Mclaughlin, 2011)

Tabel 1. Ciri yang perlu diwaspadai untuk melakukan evaluasi bahasa segera

\begin{tabular}{|c|c|c|}
\hline Usia & Reseptif & Ekspresif \\
\hline 12 bulan & - & $\begin{array}{l}\text { Tidak bersuara, menunjuk, atau } \\
\text { melakukan bahasa tubuh }\end{array}$ \\
\hline 15 bulan & $\begin{array}{l}\text { Tidak melihat atau menunjuk } 5 \\
\text { sampai } 10 \text { objek atau orang yang } \\
\text { disebutkan oleh orang tua }\end{array}$ & Tidak menyebutkan minimal 3 kata \\
\hline 18 bulan & Tidak mengikuti satu perintah & $\begin{array}{l}\text { Tidak mengatakan, "mama." "dada," } \\
\text { atau nama lainnya }\end{array}$ \\
\hline 2 tahun & $\begin{array}{l}\text { Tidak menunjuk gambar atau } \\
\text { bagian tubuh ketika disebutkan }\end{array}$ & Tidak menggunakan minimal 25 kata \\
\hline 2,5 tahun & $\begin{array}{lcr}\text { Tidak } & \text { merespons secara } & \text { verbal } \\
\text { atau mengangguk } & \text { atau } \\
\text { menggeleng ketika ditanya } & \end{array}$ & Tidak menggunakan frasa dua kata. \\
\hline 3 tahun & $\begin{array}{l}\text { Tidak mengerti kata keterangan } \\
\text { waktu atau tempat dan tidak } \\
\text { mengikuti perintah dua kegiatan }\end{array}$ & $\begin{array}{l}\text { Tidak menggunakan minimal } 200 \text { kata, } \\
\text { tidak meminta sesuatu dengan } \\
\text { menyebutkan namanya, dan } \\
\text { mengulangi kata sebagai respons } \\
\text { sebuah pertanyaan (echolalia) }\end{array}$ \\
\hline Usia kapanpun & - & $\begin{array}{l}\text { Memiliki kemunduran dalam tahapan } \\
\text { milestone bahasa. }\end{array}$ \\
\hline
\end{tabular}

Sumber: McLaughlin, Maura R., Speech and Language Delay in Children, American Family Physican, volume 83, number 10, www.aafp.org/afp, 2011. p.1187. 
Campbell et. al. (2003), menyatakan bahwa faktor-faktor penyebab yang dialami oleh anak usia 3 tahun dengan keterlambatan bicara ada enam. Pertama, rendahnya pendidikan ibu, seperti ibu tidak lulus SMA. Kedua, jenis kelamin anak adalah laki-laki. Ketiga, sejarah keluarga positif, maksudnya terdapat keturunan dalam keluarga yang mengalami keterlambatan atau gangguan bahasa. Keempat, tersedianya asuransi kesehatan untuk anak. Kelima, ras. keenam adalah kerusakan pada sistem pendengaran.

Terdapat pendapat lain mengenai faktor-faktor yang menyebabkan keterlambatan bicara atau bahasa dan membutuhkan pengobatan dapat dikelompokkan menjadi tiga, yaitu (1) faktor lingkungan yang terdiri dari status sosial ekonomi, pendidikan orang tua, kesehatan orang tua, dan tingkat keterikatan orang tua dengan anak; (2) perbedaan jenis kelamin, di mana laki-laki memiliki risiko keterlambatan bicara lebih tinggi dibandingkan dengan perempuan; (3) faktor genetik yaitu adanya sejarah keluarga yang mengalami permasalahan dalam perkembangan bahasa (Feldman, 2019).

Di Indonesia, prevelansi keterlambatan bicara pada anak adalah antara 5\%-10\% pada anak usia sekolah (Suparmiati et al., 2013). Di sebuah rumah sakit swasta besar di Jakarta, dari 260 pasien baru dengan gangguan berbicara yang dievaluasi pada tahun 2008-2009, 44,6\% pasien didiagnosis mengalami keterlambatan bicara (Dewanti, Widjaja, Tjandrajani, \& Burhany, 2012). Tidak jauh berbeda, dalam penelitian yang dilakukan di kota Bandung terhadap 498 balita baik yang berasal dari perkotaan maupun pedesaan, keterlambatan dalam aspek bahasa atau bicara menjadi yang paling banyak dialami (Fadlyana, Alisjahbana, Nelwan, Noor, \& Sofiatin, 2003). Hal ini menunjukkan jika keterlambatan atau gangguan perkembangan bicara menjadi permasalahan terbanyak yang dialami oleh anak.

Untuk mengetahui lebih lanjut mengenai faktor-faktor penyebab keterlambatan bicara yang dialami oleh anak usia prasekolah, maka peneliti akan mengidentifikasi faktor-faktor penyebab pada anak yang sedang mengalami atau sudah pernah mengalami keterlambatan bicara. Tujuan dari penelitian ini adalah untuk mengeksplorasi faktorfaktor penyebab keterlambatan bicara pada anak usia prasekolah di Kabupaten Bandung.

\section{METODE PENELITIAN}

Penelitian ini menggunakan metode kualitatif exploratory yang mengacu pada pengumpulan data yang luas, disengaja, dan sistematis yang dirancang untuk 
memaksimalkan penemuan generalisasi berdasarkan deskripsi dan pemahaman langsung dari suatu area kehidupan sosial atau psikologis (Given, 2008).

Subjek penelitian ditentukan dengan menggunakan teknik purposive sampling, karakteristik subjek digunakan sebagai dasar pemilihan (Wilmot, 2005). Karakteristik subjek dalam penelitian ini adalah (1) ibu dengan anak yang diperkirakan atau sudah didiagnosis keterlambatan bicara atau sudah pernah memeriksakan ke psikolog atau dokter anak dalam usia 2-5 tahun (usia prasekolah). Perkiraan berupa anak memiliki ciri yang perlu diwaspadai pada tabel 1; (2) keterlambatan yang dialami dapat masih berlangsung atau sudah dilewati; (3) perkembangan anak lainnya berada dalam tahap perkembangan yang normal (tidak mengalami gangguan).

Pencarian subjek dilakukan dengan menggunakan teknik snowball dikarenakan keterbatasan akses sehingga tidak diketahuinya jumlah populasi sampel (Given, 2008). Peneliti bertanya ke beberapa informan yang sekiranya mengetahui keberadaan subjek. Hingga mendapatkan tiga subjek ibu dari anak yang mengalami keterlambatan bicara, yang berada di wilayah Kabupaten Bandung.

Tabel 2. Profil Subjek

\begin{tabular}{|c|c|c|c|}
\hline Hasil data & Subjek I (GN) & Subjek II (KY) & Subjek III (TR) \\
\hline Usia Ibu & 31 tahun & 29 tahun & 36 tahun \\
\hline Usia Anak & 3 tahun 6 bulan & 2 tahun 7 bulan & 4 tahun 0 bulan \\
\hline Jenis Kelamin & Laki-laki & Laki-laki & Laki-laki \\
\hline $\begin{array}{l}\text { Pendidikan } \\
\text { Ibu }\end{array}$ & Sarjana & Sarjana & Sarjana \\
\hline $\begin{array}{l}\text { Pekerjaan } \\
\text { Ayah }\end{array}$ & Pegawai Swasta & TNI & Pegawai Swasta \\
\hline Pekerjaan Ibu & IRT & IRT & IRT \\
\hline SES Keluarga & Menengah & Menengah & Menengah \\
\hline $\begin{array}{l}\text { Pernah Ikut } \\
\text { Terapi }\end{array}$ & Ya, selama 1 tahun & Ya, hanya 1 kali & $\begin{array}{l}\text { Tidak, } \\
\text { konsultasi } \\
\text { dokter anak }\end{array}$ \\
\hline
\end{tabular}

Pengambilan data dilakukan pada bulan April 2018 menggunakan wawancara langsung dengan ibu dan observasi kepada anak. Wawancara kepada ibu dilakukan dengan tujuan mendapatkan data mengenai perkembangan bahasa anak. Dalam wawancara, pertanyaan merupakan open-ended yang disusun berdasarkan anamnesis 
untuk identifikasi keterlambatan bicara dan bahasa anak (Busari \& Weggelaar, 2004). Pertanyaannya terdiri dari sejarah kehamilan dan kelahiran meliputi pola pengasuhan ibu, perkembangan bahasa anak meliputi stimulasi yang diberikan, rekam medik kesehatan anak, sejarah keluarga, dan perkembangan belajar anak. Selain wawancara, peneliti melakukan observasi terhadap perilaku anak untuk mengamati secara langsung perkembangan bahasa anak dengan cara berinteraksi langsung dengan anak dan melihat interaksi antara ibu dan anak.

Bentuk data yang dihasilkan dari wawancara dan observasi merupakan catatancatatan penting. Data yang sudah didapatkan selanjutnya diolah dengan menggunakan teknik analisis tematik, yaitu metode untuk mengidentifikasi, menganalisis, dan melaporkan pola/tema dalam data (Braun \& Clarke, 2006). Teknik ini melalui 6 tahapan. (1) familiarisasi data; (2) menyusun kode inisial; (3) mencari tema yang sesuai; (4) mereview tema; (5) memberi nama pada tema; (6) membuat laporan. Dalam laporan ini tidak akan dituliskan secara detail tahapan yang dilalui dan akan langsung menjelaskan tema yang didapatkan dari data penelitian. Validitas yang dilakukan dalam penelitian ini adalah melakukan triangulasi data dari sumber lain yang menguatkan hasil data penelitian.

\section{HASIL PENELITIAN}

Berikut merupakan gambaran tentang karakteristik keterlambatan bicara dari tiga subjek yang merupakan ibu dan anak dalam penelitian ini. 
Tabel 3. Karakteristik keterlambatan bicara pada subjek

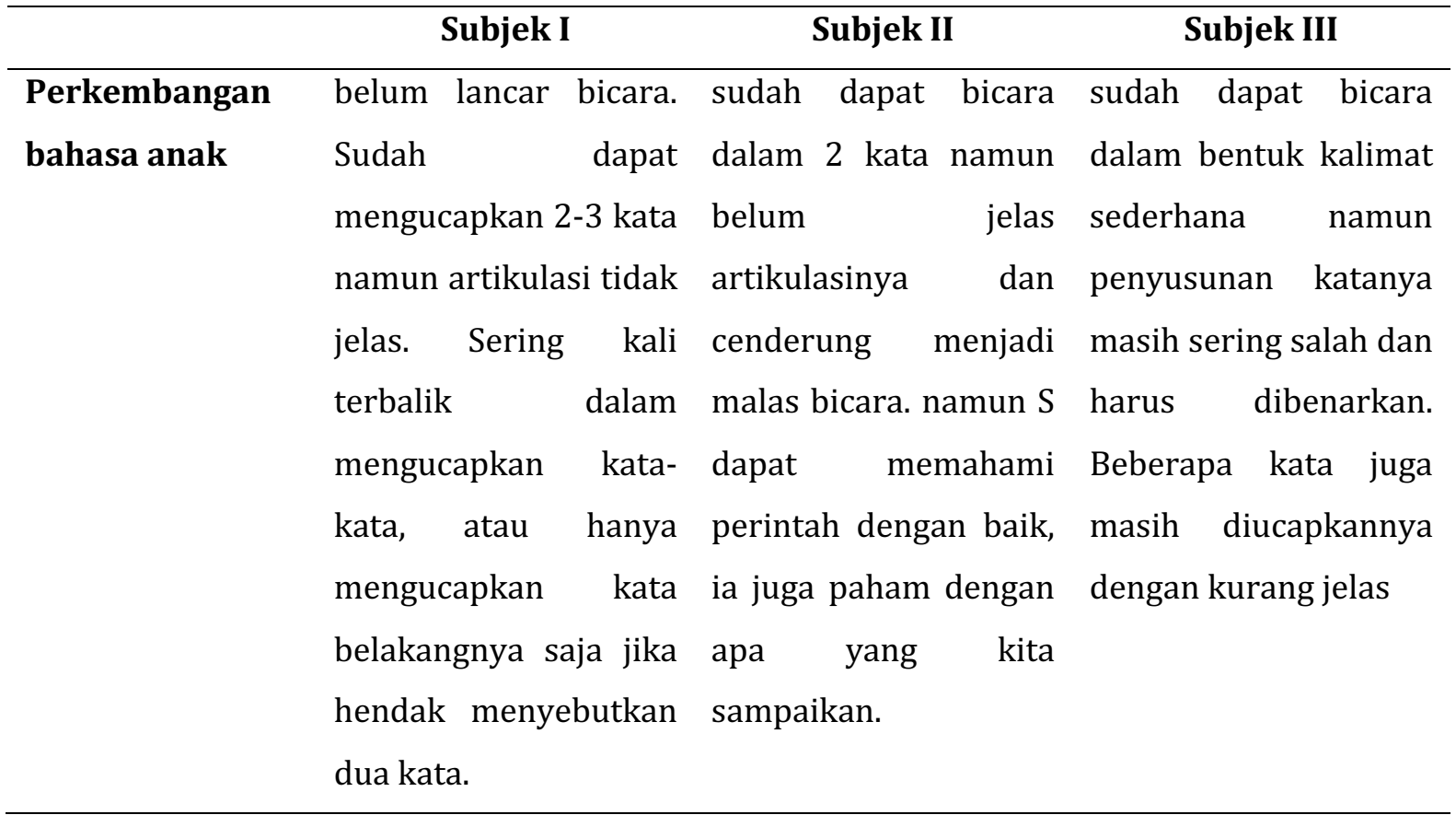

Berdasarkan analisis data yang telah dilakukan, peneliti mengelompokkan data ke dalam tiga tema utama yang menjadi faktor penyebab keterlambatan bicara anak sesuai dengan penjelasan sebelumnya, yaitu faktor lingkungan, perbedaan jenis kelamin, dan faktor genetik.

\section{Faktor lingkungan}

Pembahasan mengenai faktor lingkungan sangat luas, sehingga hasil dari data dikelompokkan kembali menjadi dua sub tema, yaitu kurang stimulus dan interaksi ibuanak.

\section{Kurang stimulus}

Dalam wawancara yang dilakukan, ibu I mengakui jika memang dirinya kurang memberikan stimulus kepada anak terutama saat usia anak lebih dini. Anak pertama yang merupakan kakak dari subjek anak memiliki perkembangan yang pesat dan cenderung bersifat aktif, sehingga ibu merasa perkembangan adik akan sama atau setidaknya tidak akan memiliki masalah apa pun dan ibu menjadi kurang memberikan stimulus untuk perkembangan bahasa anak. Hal serupa juga dialami oleh anak III. Kondisi 
keterlambatan yang dialami oleh anak dianggap wajar oleh ibu karena anak berjenis kelamin laki-laki dan membandingkannya dengan kakak yang berjenis kelamin perempuan. Anak yang berbicara dengan bahasa yang kurang dipahami, dianggap sebagai bahasa bayi yang sering dilakukan oleh anak pada umumnya. Namun hal ini berubah saat usia anak bertambah tetapi perkembangan bahasa anak tidak banyak mengalami perubahan. Ketika anak mengucapkan kata dalam bahasa bayi, ibu membiarkannya bahkan merasa hal tersebut menjadi lucu sehingga ibu tidak melakukan ralat atau membetulkan kesalahan yang dilakukan oleh anak.

\section{Interaksi ibu-anak}

Hasil observasi menunjukkan hubungan ibu anak yang sewajarnya, tidak tampak adanya kerenggangan dalam hubungan keduanya. Yang menjadi kekurangan adalah interaksi yang bersifat komunikasi dua arah yang dilakukan. Ibu I mengaku ketika usia anak lebih dini, jarang melakukan perbincangan meski untuk hal sepele kepada anak. bahkan ketika anak meminta sesuatu, ibu langsung memberikan barang yang diminta tanpa meminta anak untuk menyebutkan nama bendanya hanya agar anak tidak merengek lebih lama. Ibu jarang meluangkan waktu untuk mengobrol berdua dengan anak.

Dalam kegiatan sehari-hari, ibu membiarkan anak menonton televisi sendiri tanpa pengawasan atau menemaninya. Ibu memilih untuk mengerjakan pekerjaan rumah dan meninggalkan anak menonton televisi. Reaksi selama menonton televisi berbeda, ibu I dan III mengaku jika anak duduk tenang dan diam ketika menonton, sedangkan ibu II mengaku jika anak masih menirukan kata yang disebutkan dalam televisi meskipun tidak jelas kata yang diucapkannya. Hal ini berlangsung tidak hanya sekali dua kali, namun menjadi rutinitas yang dilakukan. Sehingga anak akan tampak fokus menonton televisi tanpa memahami apa yang sedang ditonton serta bagaimana penerapannya dalam dunia nyata.

\section{Faktor Genetik}

Dari wawancara yang dilakukan, dapat terdengar dari pengucapan ibu I ketika bercerita sering kali terbata-bata terutama pada kata awalan. Setelah banyak bercerita dan membahas sejarah keluarga, ibu mengaku jika ia mengalami gagap bicara dan 
dialaminya ketika merasakan kecemasan. Namun meski wawancara sudah berlangsung lama dan ibu sudah banyak berbicara, gagap masih beberapa kali terdengar ketika ibu mengucapkan kalimat yang panjang. Pada subjek III, ibu menyadari jika ayah dari anak mengalami keterlambatan bicara pada masa kecilnya, tetapi tidak menganggapnya menjadi masalah karena ayah pada akhirnya dapat berbicara dengan lancar seiring bertumbuhnya usia.

\section{DISKUSI}

Tujuan dari penelitian ini adalah mengeksplorasi faktor-faktor penyebab keterlambatan bicara pada anak usia prasekolah di Kabupaten Bandung. Berdasarkan pemaparan hasil, didapatkan perbedaan yang cukup signifikan apabila dibandingkan dengan penelitian yang dilakukan oleh Campbell, et. al. (2003). Dari lima faktor penyebab pada subjek penelitian ini, hanya mendapatkan kesamaan dua faktor, yaitu jenis kelamin laki-laki serta sejarah keluarga. Pengelompokkan tema dalam penelitian ini diambil dari pemaparan Feldman (2019) karena memiliki penjelasan yang lebih mendetail. Meskipun tidak semua faktor penyebab dialami oleh ketiga subjek. Lingkungan menjadi faktor penting dalam perkembangan bahasa anak, terutama dari lingkungan terdekatnya yaitu orang tua.

Faktor yang menonjol adalah interaksi dua arah antara ibu dan anak dalam bentuk percakapan. Ibu lebih banyak menganggap jika memahami perkataan anak tanpa berusaha membetulkan kata yang diucapkan oleh anak. Sehingga anak tidak belajar bagaimana mengucapkan kata yang benar. Terdapat tiga strategi yang diungkapkan oleh Santrock (2014) untuk membantu anak memperoleh bahasa. (1) Mengulangi maksud perkataan anak, misal ketika anak mengucapkan, 'anjingnya menggonggong,' maka orang tua dapat meresponnya dengan berkata, 'kapan anjingnya menggonggong?' hal ini dapat meningkatkan ketertarikan anak untuk mengucapkan kata-kata. (2) Memanjangkan kata yang diucapkan anak, misal saat anak berkata, 'anjing makan,' maka orang tua dapat membalasnya dengan mengucapkan, 'iya, anjing sedang makan.' Hal ini membantu anak memahami penyusunan kalimat yang benar seperti apa. (3) Memberikan nama pada objek, dengan meminta anak menyebutkan nama benda yang dilihatnya sehingga dapat meningkatkan jumlah penguasaan kata yang dimiliki oleh anak. 
Kurangnya interaksi antara ibu dan anak juga disebabkan oleh kegiatan seharihari di mana anak dibiarkan menonton televisi tanpa pengawasan. Dibandingkan dengan tayangan televisi, anak lebih membutuhkan keterlibatan dalam penggunaan bahasa yang hangat, saling menghormati, dan rendah stres (Feldman, 2019). Hal ini sejalan dengan penemuan yang menunjukkan jika menonton tayangan televisi memiliki pengaruh pada keterlambatan bicara sebagian dan total (Ruliati \& SW, 2015).

Salah satu faktor yang disebutkan adalah kurangnya stimulus dari orang tua. Namun stimulus seperti apa yang seharusnya diberikan kepada anak dikembalikan kepada hambatan utama yang menjadi keterlambatan bicara anak. Membacakan buku kepada anak dapat menjadi salah satu stimulus. Anak yang dibacakan buku dan semakin sering dilakukan, akan semakin baik pula kemampuan literasi serta bahasanya (Dunst, Simkus, \& Hamby, 2012). Pembacaan buku cerita menguntungkan anak ketika orang tua menjelaskan arti kalimat dengan anak dan mendorong anak untuk bertanya dan menjawab pertanyaan juga secara positif meningkatkan kemampuan kognitif anak (Santrock, 2014).

Faktor keturunan menjadi faktor yang tampak pada salah satu subjek. Meskipun gangguan yang dialami bukan spesifik merupakan keterlambatan bicara, namun masih pada satu bidang yaitu masalah pada bicara. Gangguan tersebut timbul karena kelainan genetik yang menurun dari orang tua. Biasanya juga terjadi pada salah satu atau ke dua orang tua saat kecil. Detail dari bagaimana pengaruh genetik ke gangguan bahasa sendiri belum dapat ditentukan meskipun sudah banyak penelitian yang menggambarkan hubungan keduanya (Grigorenko, 2009).

\section{KESIMPULAN DAN SARAN}

Dalam penelitian ini, dari tiga subjek didapatkan beberapa faktor penyebab keterlambatan bicara pada anak usia prasekolah yang terdiri dari faktor lingkungan dan faktor keturunan. Diharapkan dengan penelitian ini, orang tua dapat waspada mengenai kondisi anak serta dapat belajar dari keadaan orang lain yang mengalami keterlambatan bicara. Sehingga permasalahan keterlambatan bicara pada anak dapat dicegah dan ditangani lebih dini. Untuk penelitian selanjutnya, studi dengan jumlah partisipan yang banyak diperlukan untuk memperkaya data. 


\section{DAFTAR PUSTAKA}

Berk, L. E. (2013). Child Development. Pearson Education, Inc.

Busari, J. O., \& Weggelaar, N. M. (2004). How to investigate and manage the child who is slow to speak Sources and selection criteria. Bmj, 328(January), 272-276.

Campbell, T. F., Dollaghan, C. A., Rockette, H. E., Paradise, J. L., Feldman, H. M., Shriberg, L. D., ... Kurs-lasky, M. (2003). Risk Factors for Speech Delay of Unknown Origin in 3Year-Old Children, 74(2), 346-357.

Campbell, T. F., Dollaghan, C. a, Rockette, H. E., Paradise, J. L., Feldman, H. M., Shriberg, L. D., ... Kurs-Lasky, M. (2003). Risk Factors for Speech Delay of Unknown Origin in Three-Year-Old Children. Child Development, 74(2), 346-357.

Dewanti, A., Widjaja, J. A., Tjandrajani, A., \& Burhany, A. A. (2012). Karakteristik Keterlambatan Bicara di Klinik Khusus Tumbuh Kembang Rumah Sakit Anak dan Bunda Harapan Kita Tahun 2008 - 2009, 14(4), 230-234.

Dunst, C. J., Simkus, A., \& Hamby, D. W. (2012). Relationship Between Age of Onset and Frequency of Reading and Infants' and Toddlers' Early Language and Literacy Development. CELLreviews, 5.

Fadlyana, E., Alisjahbana, A., Nelwan, I., Noor, M., \& Sofiatin, Y. (2003). Pola Keterlambatan Perkembangan Balita di daerah Pedesaan dan Perkotaan Bandung, serta Faktorfaktor yang Mempengaruhinya. Sari Pediatri, 4(4), 168-175.

Feldman, H. M. (2005). Evaluation and management of language and speech disorders in preschool children. Pediatrics in Review, 26(4), 131-140. https://doi.org/10.1542/pir.26-4-131

Feldman, H. M. (2019). How young children learn language and speech. Pediatrics in Review, 40(8), 398-411. https://doi.org/10.1542/pir.2017-0325

Given, L. M. (Ed.). (2008). The Sage encyclopedia of qualitative research methods. The Sage encyclopedia of qualitative research methods. SAGE Publications, Inc.

Grigorenko, E. L. (2009). Speaking genes or genes for speaking? Deciphering the genetics of speech and language. Journal of Child Psychology and Psychiatry and Allied Disciplines, $\quad 50(1-2), \quad$ 116-125. https://doi.org/10.1111/j.14697610.2008.02006.x

Mclaughlin, M. R. (2011). Speech and Language Delay in Children, 1183-1188.

Owens, R. E. (2012). Language Development: An Introduction. https://doi.org/013258252X

Ruliati, \& SW, I. (2015). Pengaruh Menonton Televisi dengan Keterlambatan Bicara (Speech Delay) pada Balita (Studi di Graha Tumbuh Kembang Jombang). Jurnal STIKES Insan Cendekia Medika Jombang, 10(1), 70-79.

Santrock, J. W. (2014). Child development. McGraw-Hill Education.

Suparmiati, A., Ismail, D., \& Sitaresmi, M. N. (2013). Hubungan Ibu Bekerja dengan Keterlambatan Bicara pada Anak, 14(5), 3-6.

Wilmot, A. (2005). Designing sampling strategies for qualitative social research: with particular reference to the Office for National Statistics' Qualitative Respondent Register. Survey Methodology Bulletin-Office for National Statistics, 1-14. Retrieved from http://www.ons.gov.uk/ons/guide-method/method-quality/generalmethodology/data-collection-methodology/reports-and-publications/designingsampling-strategies-.pdf 